\title{
Modelling Teacher Development through Open and Distance Learning: A Zimbabwean Experience
}

\author{
Moffat C. Tarusikirwa \\ Faculty of Arts and Education, Zimbabwe Open University, Zimbabwe
}

Copyright $\bigcirc 2016$ by authors, all rights reserved. Authors agree that this article remains permanently open access under the terms of the Creative Commons Attribution License 4.0 International License

\begin{abstract}
Historically, in Southern Rhodesia, now Zimbabwe, Standards 3, 4, 5 and 6 would teach during the school term and attend teacher training during the school holidays. This was mostly in Missionary institutions. Later, these organisations changed into full-time teacher training institutions. Then teacher training lasted two years. Students would spend time in college and in the field. Some teachers were certified because of good performance, without having attended any teacher development college. Some, for example holders of Primary Teacher Lower Course (P.T.L.) who passed the Cambridge General School Certificate, GCE were given an examination and upgraded to the Primary Teacher Higher Course (P.T.H.) qualification. Among the past models are the -3-3-3, the -3-3-3-3 and the ZINTEC (Zimbabwe Integrated Teacher Education Course) model of teacher development used in conventional colleges. Currently, conventional colleges use the 2-5-2 model. For the purpose of this paper, the Zimbabwe Open University ODL model of Teacher Development will be discussed. In this model, student teachers are continually teaching in schools, while at the same time undergoing teacher development. The purpose of this model is to make it cheaper to produce teachers as it has advantages of producing large numbers of teachers at the same time as they teach in the schools making it economic for the country.
\end{abstract}

Keywords Open and Distance Learning (ODL), Modelling, Teacher Development

\section{Introduction}

This paper is going to discuss the teacher development models used in Zimbabwe in the early years of teacher training to the newer and current models of teacher development at use today, particularly the Open and Distance Learning model of teacher development used by the Zimbabwe Open University. Finally the paper will discuss the challenges and advantages of teacher development through ODL as surfaced by a survey of 200 Open and
Distance Education practitioners.

\section{Literature Review}

Scholars have defined Distance education as an educational process in which a significant proportion of the teaching is conducted by someone removed in space and/or time from the learner, see Brown and Brown [1]. Open learning, in turn, is an organised educational activity, based on the use of teaching materials, in which constraints on study are minimised in terms either of access, or of time and place, pace, method of study, or any combination of these. The term 'open and distance learning' is used as an umbrella term to cover educational approaches of this kind that reach teachers in their schools, provide learning resources for them, or enable them to qualify without attending college in person, or open up new opportunities for keeping up to date no matter where or when they want to study, see UNESCO [2]. The flexibility inherent in open and distance learning, and the fact that it can be combined with a full or near full-time job, makes it particularly appropriate for the often widely distributed force of teachers and school managers. Historically, on the African continent, UNISA (University of South Africa), has been a major provider of distance education and teacher education at tertiary level throughout the southern African region from the 1940s, see UNESCO $[2,3]$. In the early 1980 s and 1990 s UNISA's main role in teacher education was to provide upgrading programmes for serving primary and secondary teachers at the diploma and graduate levels. From the mid-1990s, UNISA has undergone a period of change in attempting to respond to new national priorities in teacher education and to improve the quality of its services, for example, learner support. Some of the programmes offered since 1998 include Bachelor's degree level courses for primary and secondary teachers. Print has been used as the dominant medium of instruction complemented by face-to-face contact sessions or discussion class groups, practical work and some on-line learning activities. UNISA has since integrated (WWW) technologies into their programmes, see UNESCO [2,3]. In the case of 
China, the provision of large-scale teacher education through a national distance teaching institution, the China Television Teachers College (CTVTC), a part of the China Central Radio and Television University (CCRTVU) was done since 1994. Distance education is included in China's strategic planning for teacher education and plays a significant role in initial teacher education and continuing professional development. A number of other countries on a global basis also offered Teacher Education through Distance Learning as revealed by a number of case studies contracted by UNESCO [2]. For example, Chile, Brazil, Burkina Faso, India, Nigeria, Mongolia and the United Kingdom.

According to UNESCO [2], the studies represent an interesting mix of applications of different modes of distance learning. In the views of UNESCO [2], globally, there is still the need for more and better teachers. In their views, there were still more than 100 million children out of school, who need teachers as the world moved towards 2015 targeted as the year of education for all. According to UNESCO [2], the world needs to raise the skills of the existing 60 million teachers, too many of whom are untrained and unqualified. In the thinking of UNESCO [2], beyond 2015, the skills and knowledge needed by all teachers are no longer fixed and familiar targets but moving ones. Hence, they say, teachers need more opportunities than ever before to go on learning throughout their careers. UNESCO [2] asserts that one of the ways of strengthening the teaching profession is to use distance education or open and distance learning. From the leadership side UNESCO [2] looked at organisational structures, and the kinds of organisations that provide teacher-education programmes, and the different patterns of funding. Also looked at were the technologies, ranging from print to computers, and the relationship between work done through the technologies and work done face-to-face, including all-important issues about classroom practice. According to UNESCO [2,3], many countries still do not have enough teachers. In some, the expansion needed in the teaching force is far beyond the capacity of traditional colleges. The supply of teachers is also adversely affected in countries where retention rates are low for newly trained teachers or where significant numbers of teachers are being lost through HIV-AIDS or in rural areas which have difficulties in recruiting and retaining teachers. Teacher quality is an issue in most countries. Many teachers are untrained or underqualified or teaching subjects in which they are not qualified or trained. In addition, teachers face a widening range of demands and roles UNESCO [2,3]. National governments, international organisations and specific circumstances continually set new goals: gender parity by 2005 and universal basic education by 2015 ; inclusive education; education for democracy, peace and social cohesion; multi-grade teaching; increased accountability for achieving learning targets; the development of learners who are self-managing and independent, skilled in critical thinking and problem solving, equipped with life-skills; the preparation of learners who are competent for knowledge-based economies, capable in the use of information technology; and the expansion of teachers' roles to include social work in communities where child-headed households and orphans are common as a result of HIV-AIDS, i.e. according to UNESCO and OECD [2, 5]. In the light of the foregoing, Distance education has been used to teach, support and develop teachers for many years.

History has witnessed, distance education for teachers, especially in developing countries, characterised by short-term projects which did not go far in solving the problem of teacher shortage. Often, established distance teaching universities have provided teacher education programmes alongside others and increased access to programmes and professional development opportunities for teachers. According to UNESCO [2,3] sponsored case studies, distance education for teachers receives funds from all four of the most usual sources of funds for education such as government budgets, student fees, the private and NGO sector and from funding agencies. Several programmes receive funding from a combination of sources so that, for example, the programmes in both China and Nigeria are funded partly by government, partly by student fees. The African Virtual University provides online and distance education services to many existing universities across Africa. The AVU has more than 50 academic partner institutions in more than 27 countries in Africa. It helps partner institutions set up local study centres in different countries, where programmes from numerous partner institutions, learner support and guidance, and access to e-learning technologies are made available. To date there are 10 such centres, in 10 different countries. The main focus at the moment is on teacher education, with four bachelor programs for teachers of math, physics, chemistry and biology, offered through a consortium of 12 universities in 10 African countries. Delivery is mixed mode, through online learning and attendance at local centres. AVU though also offers or facilitates a wide range of webinars, self-learning programmes, workshops, and certificate/diploma programmes, in collaboration with the partner institutions. AVU also offers student scholarships, see UNESCO [4], UNESCO [2,3], OECD [5]. MOOCS can also be used, see Robinson, B. in J. Lynch [6].

In the early years of colonial rule in Zimbabwe, the education of African people was entrusted to missionaries. During the late nineteenth to early twentieth century, i.e. 1901 to 1924, there were very few local schools and teacher training centres, see Siyakwazi [7]. Most people went to South Africa for higher education as local schools run by missionaries for Africans went as far as standard 3. European settlers went to Europe or South Africa for their education and training. Teacher training for Africans was only for primary school teachers done by missionaries. The missionary was driven by the command to preach the gospel and the need for African converts in the schools. As the need for education started to rise, the number of mission schools increased from 3 in 1901 to 1216 in 1924. The number of students also increased from 265 in 1901 to 77610 in 1924, see Siyakwazi [7]. As such, the need for teachers to teach in 
village schools paused an urgent reality. According to Bone [10] in Siyakwazi [7], the average academic qualification in the country was standard 2 or 3 . Initially trained teachers were recruited from RSA (Republic of South Africa) and Nyasaland now, Malawi. According to the Director of African Education Report [8], missionary teachers did not remain in the schools long enough. They were passersby. The quality of teachers produced by missionaries was below par. The model employed to train teachers at the time involved 3 years of teacher training after standard 3, see Hadfield Commission Report [9]. The model employed a common syllabus drawn up by the Department of Education. In 1925, the Missionary School teacher training model is summed up by Bone [10] as chaotic and desperately needed planning for order and control. These centres were run by clergy Principals who were not trained for the job. The model used for teacher training proved inadequate and by 1951 , untrained teachers in schools in the country stood at 70.6 percent (Kerr Commission Report [11]. Among the reasons advanced for the failure of the model were poor planning, unattractiveness of the teaching profession among others, see Kerr Commission Report [11].

In 1928, a new teacher training model was born with minimum entry requirements of standard 2 and an age range of 12 to 50 years old and in 1929 age requirement changed to 16- 25 years. Furthermore, candidates for teacher training were required to have passed standard 3 as pronounced by Government notice no. 676, November [12]. By 1939, the minimum qualification was set at standard 4 and the age range remained at $16-25$ years. According to Rea [13], this model was beset with challenges of religious discrimination as nonconformists were excluded from teacher training with emphasis being placed on church affiliation rather than scholastic consideration. All colleges were residential with a practicing school within the college area for Teaching Practice as part of training. This model was a 3 year course model, all students had a uniform examination from a prescribed Department of Education syllabus. School Inspectors from the Education Department conducted the examinations. Students were issued with a provisional certificate endorsed by the school inspector after 1 year satisfactory teaching service, see Government notice No. 676, November 15 [12]. According to the Hadfield Commission Report [9], the 3 year course comprised such subjects as theory and practice of teaching and industrial work among others.

As shown by the table 1, during the early years of teacher training, certain subjects were segregated by gender with women doing Needlework, Domestic duties and gardening as practicals as opposed to Road making, Tree planting, Agriculture and Manual training for men. Such unjustified gender discrimination seems to have been a symptom of the time bolstered by religious beliefs and attitudes which are strongly embedded with patriarchal norms and the hegemony of the division of labour between men and women according to physical attributes and dominance.
Table 1. Distribution of subjects taught to trainee teachers by gender

\begin{tabular}{|c|c|}
\hline Male & Female \\
\hline Arithmetic & Arithmetic \\
\hline English & English \\
\hline Geography & Geography \\
\hline History & History \\
\hline Physical Exercises & Physical Exercises \\
\hline Hygiene & Hygiene \\
\hline School Method & School Method \\
\hline Reading from Bible & Reading from Bible \\
\hline Practice teaching & Practice teaching \\
\hline Black board work & Black board work \\
\hline Drawing & Drawing \\
\hline Industrial work & Industrial work \\
\hline Road making & Needlework \\
\hline Tree planting & Domestic duties \\
\hline Agriculture & Gardening \\
\hline Manual training & \\
\hline
\end{tabular}

Ref.: Hadfield Commission Report, pp 125 - 126 [9]

Table 2. Distribution of Teacher Training Schools in Zimbabwe in 1934 by Church Denomination

\begin{tabular}{|c|c|}
\hline School & Denomination \\
\hline Solusi & Seven Day Adventist \\
\hline Kutama & Roman Catholic \\
\hline Morgenster & Dutch Reformed Church \\
\hline St. Augustine & Anglican \\
\hline Hope Fountain & London Missionary Society \\
\hline Howard & Wesleyan \\
\hline Waddilove & American Board \\
\hline Mt. Selinda & American Methodist \\
\hline Old Umtali & Seventh Day Adventist \\
\hline Inyanga & Roman Catholic \\
\hline Triashill & Methodist Episcopal \\
\hline Hartzell & Methodist \\
\hline Tegwani & Roman Catholic \\
\hline Monte Cassino & London Missionary Society \\
\hline Inyati Society & Brethren in Christ \\
\hline Matopo &
\end{tabular}

Source: A/Director of Native Development Report 1934:5 [14]

The leading Teacher Training schools in 1933 were Howard, Kutama and Morgenster. In 1939, a new model in the form of a two year in-service course for PTL teachers who had done the external Junior Certificate was introduced. Those who did this course could be promoted to the PTH qualification. It was envisaged that this would improve teacher quality in the face of such problems as the dogmatic use of teachers' guides and scheme books by teachers, shortage of books inter alia. 
In 1949, a new model of teacher training was born, namely PTH (Primary Teacher Higher) at Kutama. The course ran for two years and the entry qualification was 10 years of secondary school or Southern Rhodesia Junior Certificate of Education or Cambridge School Certificate or equivalent 12 years of schooling. Soon after a semblance of Distance Teacher training came partly through the recommendation by the Kerr Commission in 1951 of an Emergency Teacher Training Scheme/Model for 4434 untrained teachers who were employed in 1950 in aided Primary Schools. This model of teacher training consisted of a 13 month course of teacher training. In this model, after the initial training, students were expected to complete 1 year of part-time study. Thereafter, they were placed on a further year's probation period and if recommended by school inspectors, they were absorbed into the school system and given the same qualifications as two year post- standard 6 PTH qualification. The age range was 18 to 40 years.

Table 3. Distribution of training centres for the new model course by Church Denomination

\begin{tabular}{|c|c|}
\hline Name of Centre & Denomination \\
\hline St. Augustine's & Anglican \\
\hline Dadaya & Church of Christ \\
\hline Morgenster & Dutch Reformed Church \\
\hline Waddlove & Methodist Church \\
\hline Gokomere & Roman Catholic \\
\hline Kutama & Roman Catholic \\
\hline
\end{tabular}

Source: Director of Native Development Report, 1953:32 [15]

Briefly, Missionaries trained teachers in Zimbabwe through the use of 2 two year models from 1928 to 1963 up to the two qualifications of PTL and PTH. At some of these teacher training centres, the model comprised a school within the mission centre for teaching practice during training. However, the period 1965 to 1976 , witnessed the introduction of government teacher training colleges in addition to mission centres and new models of teacher training. Government became increasingly involved in Primary teacher training and introduced a number of new government colleges, see Siyakwazi and Siyakwazi [16]. The University of Rhodesia, was roped in to play a role in developing teacher training courses together with the colleges. This period witnessed the introduction of a number of teacher training models. Firstly there was the T4 model of teacher training. This model replaced the PTL and was primarily for women teachers of Grades 1 and 2. The T4 model of teacher training emphasised discovery methods and group teaching, see Annual Report of the Secretary for African Education [17]. This model emulated similar models in the USA and UK at the time. Training was over a 2 year period. Additionally, the model concentrated on infant methods and individual work in child study. A second model that was introduced, was the T3, model which replaced the PTH course. It stretched for 3 years and was meant for teachers of grades 3 to 7 . The content was made up of a section of professional subjects, practical teaching and
Education 1 and 2. A second section covered academic subjects of English, Mathematics, Science and Agriculture, Geography, History, Religious Education, Music and African Languages. The model emphasised the new approach to teaching methods. Later on in 1975, the T3 model was split into a course for Infant Teachers and that for Junior Teachers. The entry qualification was the Cambridge School Certificate as from 1976. Large colleges of teacher training were born although some missionary colleges remained small. Siyakwazi and Siyakwazi [16] posits that colleges by this time were expected to maintain high standards and apply for Asssociatships with the University of Rhodesia.

Previously, according to Siyakwazi [7], the involvement of the government in teacher training and the advent of large colleges had ushered in a multiplicity of teacher training models in Zimbabwe. These spanned over a wide area of specialisation in Teacher Development. For example, the Education policy [18] had pronounced on a number of teacher training models covering from the training of infant teachers to Secondary School teachers as shown below.

Table 4. Teacher Training models as per the Education Policy of 1966 [18]

\begin{tabular}{|c|c|c|c|}
\hline $\begin{array}{c}\text { Grades } \\
\text { Taught }\end{array}$ & Qualification & $\begin{array}{c}\text { Length } \\
\text { (Years) }\end{array}$ & Nature of Work \\
\hline 1 and 2 & T4 & 2 & Infants teaching \\
\hline 3 to 7 & T3 & 3 & $\begin{array}{c}\text { Primary School } \\
\text { Teaching }\end{array}$ \\
\hline 8 to 11 & T2B & 2 & $\begin{array}{c}\text { Vocational Sec. } \\
\text { School }\end{array}$ \\
\hline Forms 1 to 3 & T2A & 2 & $\begin{array}{c}\text { Secondary } \\
\text { School }\end{array}$ \\
\hline Forms 1 to 4 & T1 & 3 & $\begin{array}{c}\text { Secondary } \\
\text { School }\end{array}$ \\
\hline
\end{tabular}

The general model used for teacher training across the board for 3 year courses was as follows:

\begin{tabular}{|c|c|c|c|}
\hline Year & Term $1-12$ wks & $\begin{array}{c}\text { Term } 2-12 \\
\text { wks }\end{array}$ & $\begin{array}{c}\text { Term } 3-12 \\
\text { wks }\end{array}$ \\
\hline $1^{\text {st }}$ & Spent at College & $\begin{array}{c}\text { Spent at } \\
\text { College }\end{array}$ & $\begin{array}{c}\text { Spent at } \\
\text { College }\end{array}$ \\
\hline \multirow{2}{*}{$2^{\text {nd }}$} & $\begin{array}{c}\text { Spent in } \\
\text { Schools doing } \\
\text { Teaching } \\
\text { Practice (TP) }\end{array}$ & $\begin{array}{c}\text { Spent in } \\
\text { Schools doing } \\
\text { TP }\end{array}$ & $\begin{array}{c}\text { Spent in } \\
\text { Schools doing } \\
\text { TP }\end{array}$ \\
\hline $3^{\text {rd }}$ & Spent at College & $\begin{array}{c}\text { Spent at } \\
\text { College }\end{array}$ & $\begin{array}{c}\text { Spent at } \\
\text { College }\end{array}$ \\
\hline
\end{tabular}

To sum up the table above, the model involved students doing theory and content courses on teacher training at college for their $1^{\text {st }}$ year of study ending with examinations. In the second year, the students would be deployed in schools across the country and do Teaching Practice. They would practically learn how to teach while teaching under the supervision of mentors and inspectors in schools. In the $3^{\text {rd }}$ and final year of training, the students would come back to college for more theory and content subjects of teaching and end up with examinations before graduating as illustrated below. 


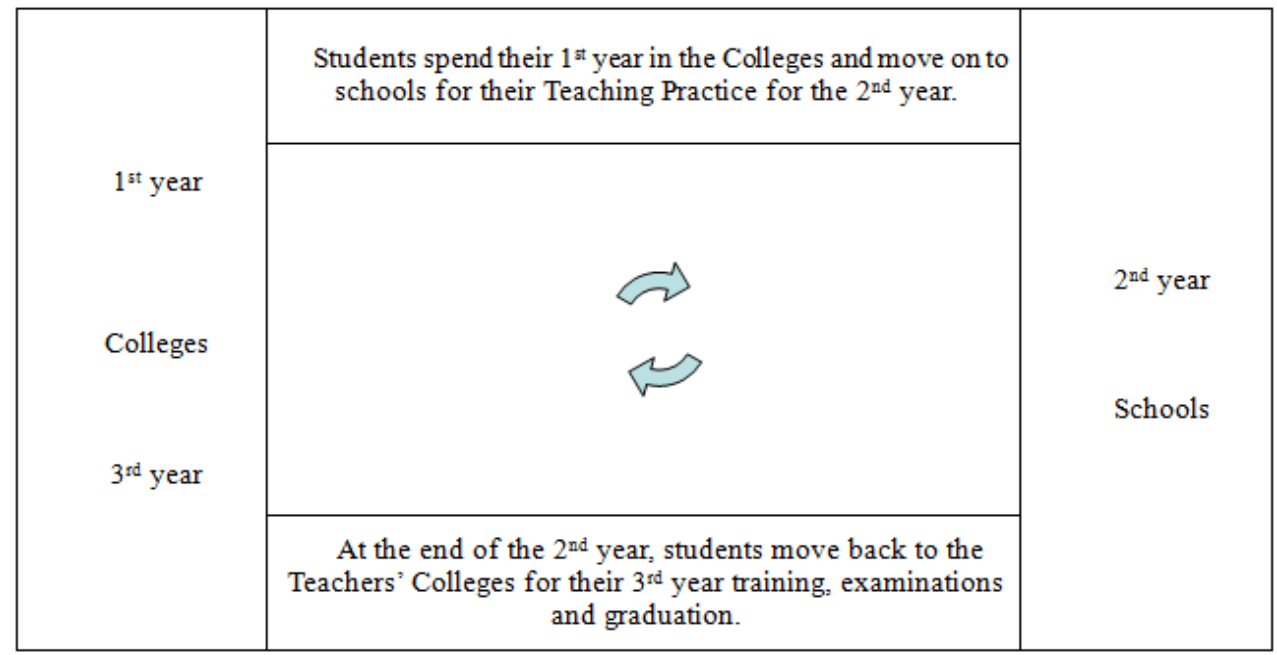

\section{Modelling Teacher Development through ODL}

The last model discussed by Siyakwazi [7] was the 3-3-3 model of Teacher Development. This was later modified with the $1^{\text {st }}$ year of training being spent in the schools, $2^{\text {nd }}$ year in colleges and $3^{\text {rd }}$ year in schools as follows:

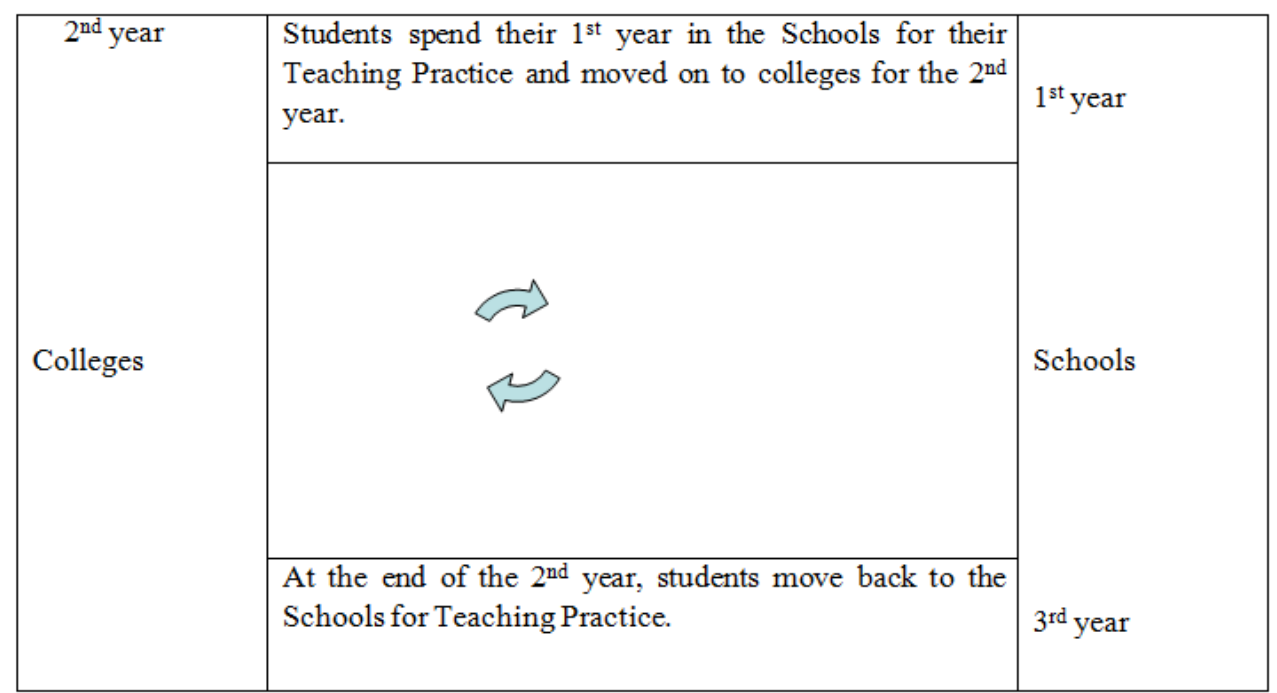

In this $1^{\text {st }}$ model, teacher training consisted of three years of teacher development, that is - 3-3-3: In this model teachers were trained for three years. In the three years, the first 3 terms of training $\left(1^{\text {st }}\right.$ year) were spent in schools out of college while the next 3 terms $\left(2^{\text {nd }}\right.$ year $)$ were spent in college and the final 3 terms ( $3^{\text {rd }}$ year) were spent in schools/ out of college, clearly an ODL approach to Teacher Development, the Zimbabwe Open University approach.

The $2^{\text {nd }}$ model, consisted of four years $-3-3-3-3$ : This model was adopted later for Conventional colleges. In this model the first year was spent in college, the $2^{\text {nd }}$ year out in schools, $3^{\text {rd }}$ year in college and the final year was spent out in schools. The ZINTEC model for Teacher development used in Zimbabwe soon after independence in 1980 to counter the huge shortage of teachers in schools was a semblance of this model, see Burns [19]. Following the massification of both primary and secondary education in Zimbabwe soon after independence, the ZINTEC model for teacher development was developed. The original ZINTEC (Zimbabwe Integrated Teacher Education Course) model was four years long. Students were assigned to full classes and there was no mentor. The model heavily depended on modules, vacation sessions and seminars. There was a Department of Distance Education within the Ministry of Higher Education that was responsible for producing modules for all primary school curriculum subjects to guide students.

Currently, conventional colleges in Zimbabwe use the 2-5-2 model of teacher development. In this current model of Teacher Development, student teachers spend the $1^{\text {st }}$ two terms of their training in Colleges. This is followed by a period of 5 terms of training out in schools and finally by two terms back in college. For the most part of their training, students are out in schools teaching under the supervision of College, University and School/Ministry staff. This model of teacher development is heavily imbedded with aspects of ODL in every respect as displayed below. 


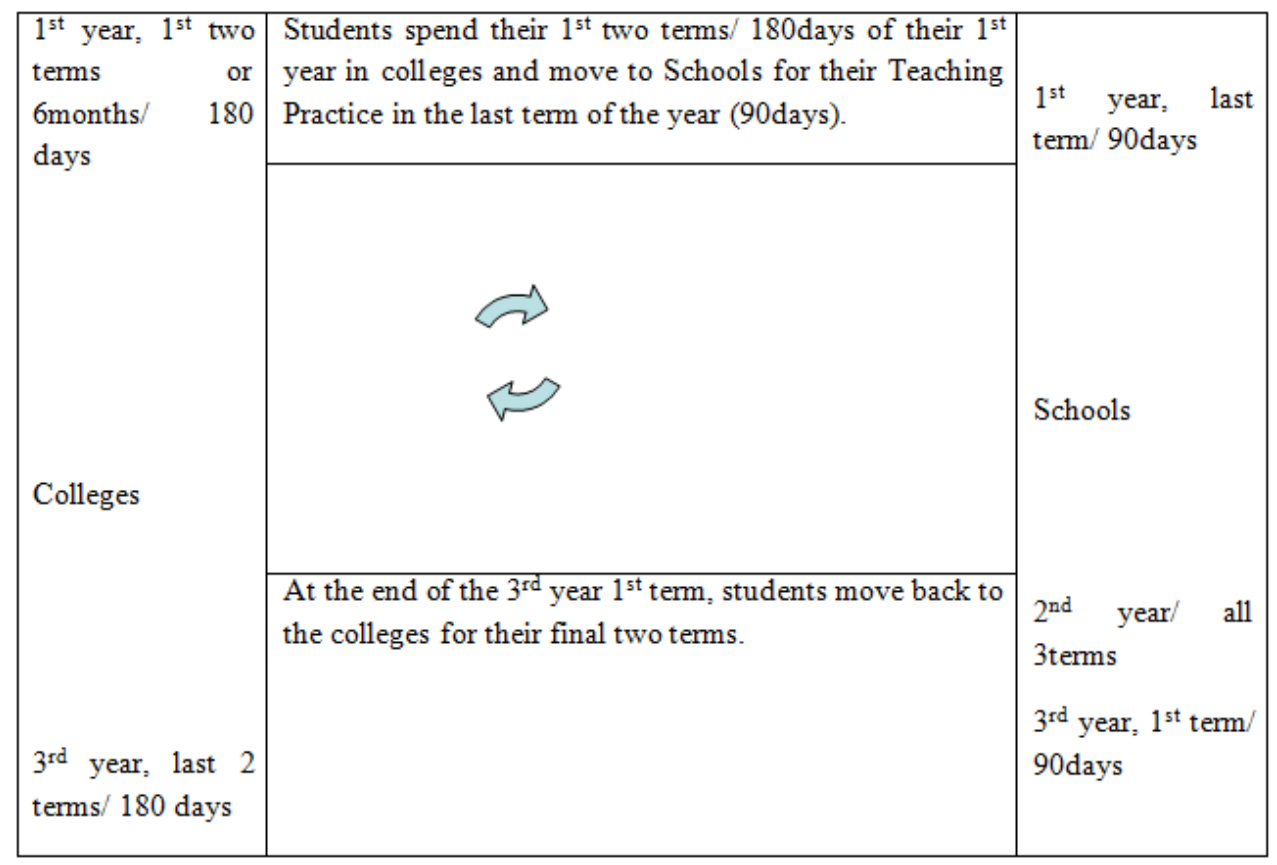

The 2-5-2 model of teacher development currently used by conventional teacher training colleges in Zimbabwe today illustrated above was adopted by all teacher training colleges in Zimbabwe after the 4 year model of teacher training was abandoned.

Traditionally in Zimbabwe, as outlined above, Teacher Development was a prerogative of the government through Teachers' Colleges and a few Missionary School Colleges under the tutelage of the University of Zimbabwe. However, due to a large number of vacant posts in schools $(+22000)$, in the early 2000's, the Zimbabwe Open University became a critical player in teacher development in Zimbabwe. The Zimbabwe Open University has the capacity to develop teachers through Open and Distance Learning, a method that has been used widely locally, regionally and globally across countries ranging from South America, China, Europe and Africa itself inter alia. The Zimbabwe Open University student teachers are continually teaching in schools, while at the same time undergoing teacher development. Student teachers attend weekend tutorials where they do peer and micro teaching, group discussions and meet the lecturers face-to-face. Furthermore, students are tutored in educational foundation subjects and primary school curriculum subjects by experienced lecturers. This is in line with other teacher development institutions in Zimbabwe. Additionally, students are provided with well - written modules authored by experienced university and college lecturers. These modules are highly sought after by university lecturers and students all over the country.

Modules are a very effective method of teaching because they are consistent in delivery, student - centred and well researched. Students have access to their tutors 24 hours a day through ICT, modules, cell phones, etc. As ICT tutoring becomes a reality at ZOU through My Vista, an online teaching and learning platform, students have gained unlimited access to learning materials and tutors 24/7. Additionally, apart from learning while they are teaching in the schools which exposes them to more Teaching Practice under the supervision of school based mentors, School Heads and Education Officers from the Ministry of Education, students undergo a 2 semester, 1 year Teaching Practice period supervised and monitored by the University's Department of Teacher Development. The model is illustrated below.

The ZOU ODL model of Teacher Development by Moffat C. Tarusikirwa, 2013 


\begin{tabular}{|c|c|c|c|}
\hline $\begin{array}{l}\text { 13. Graduation } \\
\text { Capping and } \\
\text { Certification Ceremony } \\
\text { at the National Centre }\end{array}$ & $\begin{array}{l}\text { 14. National Service } \\
\text { Graduates employed by } \\
\text { Schools, Universities, } \\
\text { NGO's etc. }\end{array}$ & $\begin{array}{l}\text { 1. Admission } \\
\text { Applications at } 10 \\
\text { Regional Campuses or } \\
\text { through e-mail. }\end{array}$ & $\begin{array}{l}\text { 2. Registration } \\
\text { Students register and } \\
\text { receive assignments, } \\
\text { tutorial letters, modules } \\
\text { etc. }\end{array}$ \\
\hline $\begin{array}{l}\text { 12. Examinations } \\
\text { Writing in Regional } \\
\text { Campuses, centralised } \\
\text { marking, processing and } \\
\text { publication of results. }\end{array}$ & & & $\begin{array}{l}\text { 3. Orientation } \\
\text { Students meet tutors for } \\
\text { programme overview } \\
\text { and introduction to } \\
\text { ODL mode of leaming }\end{array}$ \\
\hline $\begin{array}{l}\text { 11. Research Project } \\
\text { Action research and } \\
\text { writing assisted by } \\
\text { research guide and } \\
\text { consulting supervisors. }\end{array}$ & $<$ & & $\begin{array}{l}\text { 4. Tutorials } \\
\begin{array}{llr}\text { Meeting for tutorials, } \\
\text { group discussions, } \\
\text { question and answer } \\
\text { sessions etc } & \text { (using } \\
\text { modules) } & \text { during } \\
\text { weekend } & \text { school } \\
\text { sessions. } & \end{array}\end{array}$ \\
\hline $\begin{array}{l}\text { 10. Teaching Practice } \\
\text { Supervision by tutors } \\
\text { and mentors (using } \\
\text { mentoring guide) and } \\
\text { extemal assessment. }\end{array}$ & & & $\begin{array}{l}\text { 5. ODL delivery mode } \\
\text { Use of methods such as } \\
\text { modules, electronic } \\
\text { materials, tutorials and } \\
\text { My Vista platform. }\end{array}$ \\
\hline $\begin{array}{l}\text { 9. Micro Teaching } \\
\text { Teaching in groups and } \\
\text { as individuals in schools } \\
\text { under continuous tutor } \\
\text { supervision. }\end{array}$ & 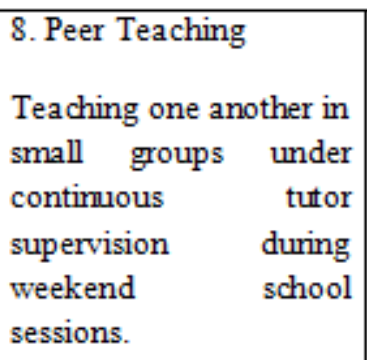 & $\begin{array}{l}\text { 7. Assignments } \\
\text { Writing, submitting, } \\
\text { marking and feedback } \\
\text { given using hard or soft } \\
\text { copies. }\end{array}$ & $\begin{array}{l}\text { 6. Independent study } \\
\text { Self managed study } \\
\text { (self motivated, flexible } \\
\text { time, verues plus full } \\
\text { time teaching in } \\
\text { schools). }\end{array}$ \\
\hline
\end{tabular}

\section{Applicability of the ZOU ODL Model}

The ZOU model for teacher development through ODL was a result of certain factors affecting the delivery of Teacher Development through ODL. For example, when ZOU first embarked on Teacher Development in 2006, there were many critics who were of the view that this could never be done. Hence, the need for the development of the model to guide teacher development through ODL. The model now provides a step by step action plan for all to follow and it's open to improvement as colleagues make the necessary feedback. A survey carried out among 200 academic staff at
ZOU in February 2013 surfaced a number of challenges and advantages of using the ZOU ODL model of Teacher Development as follows.

Challenges arising from the use of the model include the following:

1. Module availability: In this model, students should be supplied with hard copy modules or electronic copies of modules through My Vista platform. However, hard copy modules are demanding to produce both financially as well as volumes required particularly where large student numbers are involved. There is also the distribution logistics over 
a large geographical area which can be a nightmare. With advancement in technology, soft copies of the module sent electronically or distributed on $\mathrm{CD}$ ROM may at times solve the problem. However, in a poor developing country like Zimbabwe, most students struggle with poverty and cannot afford electronic gadgets such as computers and tablets in order for them to access the electronic copies of the modules. In that regard, students demand to be supplied with their hard copies of the modules. This challenge is exacerbated by poor internet networks in certain parts of the country for those who can afford electronic gadgets.

2. Mentor availability: Due to the shortage of trained teachers, particularly in remote rural areas, sometimes students are working at a school where there are no trained colleagues to act as mentors to them. In such a scenario, the student has to struggle alone with the help of the University tutors as mentors.

3. Teaching Practice Supervision: In ODL, student numbers can be very large requiring a sizable number of supervisors. This is sometimes challenged by unavailability of qualified supervisors with the right training and experience to supervise students on TP. These have to be experienced qualified teachers, education officers, teacher educators and university teacher trained and experienced practitioners. It cannot be anybody; hence it is often a challenge to get the required supervisors for TP.

4. Transport and road infrastructure: The road network in Zimbabwe's rural areas is in a deplorable state of affairs with most roads being gravel and sometimes impassable particularly during the wet season. Such a scenario makes it difficult for TP supervisors to travel to see students in remote parts of the country. They often have to negotiate through difficult terrain in order to get to the schools where the students are deployed. Moreover, due to the large number of students to be visited for TP, the number of TP vehicles required for this exercise is sometimes large. These have to be robust four wheel drive and all terrain vehicles to be able to plough through the aforementioned dilapidated road network. The acquisition of such vehicles by universities is made difficult by a poor economic condition synonymous with a lowly developed country like Zimbabwe exacerbated by donor fatigue. Hence the transport for TP supervisors is a challenge. There is the need to build a pool of robust vehicles for TP supervision purposes.

5. Communication: Additionally, communication with students is sometimes a challenge as there are no or poor communication networks in certain parts of the country. Sometimes students are moved and deployed elsewhere by their employer, at short notice hence the university may find that a student has changed base at the time of the visit by supervisors.

6. Placing students for TP: Unless students are employed in a school when they start their course, it is sometimes a challenge for them to get a school placing for TP. Some school authorities do not readily take in ODL student teachers depending on the head's biases as some people still have negative stereotype views about learning through ODL.

7. Accommodation for TP staff: Visiting TP supervisors sometimes experience problems with finding suitable overnight accommodation in remote parts of the country as there are no hotels in these parts. They may have to put up in vehicles or in classrooms.

8. TP allowances for staff: Due to fiscus difficulties, funding for TP supervision is sometimes inadequate hence TP allowances may not be enough or too small for the prevailing accommodation charges on the market inter alia. Such a scenario imposes further difficulties on the TP supervisor.

9. Socio - political factors: A further challenge comes from the environment in which the student teacher is deployed. Student teachers have to fit into the community in which they are deployed and in some places, students may experience difficulties of a socio - political nature depending with their own orientation.

10. Tutor availability: Furthermore, the challenge of tutor availability is sometimes real depending with the subjects the students are specialising in. Certain subjects are still a shortage area, for example the STEM subjects of Mathematics, Physics, Chemistry etc. Also the laboratory infrastructure may be non existent in certain parts of the country.

11. Large student numbers make it difficult to organise Peer and Micro Teaching as it requires a sufficiently big pool of supervisors and mentors among other resources. This is a very important component of Teacher Development which needs careful attention.

Despite the above challenges being surfaced by the students, the implementation is manageable as the model is aimed at developing teachers while they earn and carry out their normal life activities within their communities and families. Hence the cost is even lowered as travel is limited. Arguably, there are challenges of placing school leavers in the schools for their Teaching Practice sessions. However, recently, the use of this model has been enhanced through the signing of a MoA (Memorandum of Agreement) with the Ministry of Primary and Secondary Education and UNICEF for a funded Teacher Development Programme through the use of the model. It is also acknowledged that indeed competent people are required for a good ODL practice. The good thing is that with the development of ICT platforms for e-learning, this model will rely more and more on a fewer 
subject specialists interacting with large student numbers on these platforms, hence cutting the cost. There is however a challenge in terms of access to ICT gadgets and internet networks in remote rural areas by the poor students and that is acknowledged. As a way forward, in the near future, tablets will be purchased for all students and these will be loaded with learning materials in order to ease these challenges. In the views of Burns [19], this has been used successfully in other countries, for example in South Korea, mobile phones have been employed at great length for both teaching and student access to learning materials.

It is acknowledged that there are critics of the model in the form of some old fashioned Ministry of Education Officials or rather stereotypes who believe in conventional education as the way to develop teachers. Moreover, Burns [19], surfaces a number of Teacher Development models that have been used both in Southern Africa, Africa in general and in other parts of the world and provides some of the criticisms of such models. The current model is included to an extent as Burns [19] also raises the issues of supervisor shortages in Zimbabwe as a factor that may affect teacher development with respect to the ZINTEC model of Teacher Development, once used in Zimbabwe in which trainee teachers spent most of their time in schools as advocated by the current model. The involvement of the Ministry of Primary and Secondary Education and UNICEF in this project helps a lot in alleviating the effects of some of the above challenges. UNICEF together with the Ministry has funded some of the students with fee payment. Moreover, they have funded for the purchase of computer lab equipment in certain Regional Campuses for the benefit of the students.

While ODL was previously used and confused with a mode of training used to upgrade Teachers' s qualifications or to equip school heads with skills to head and run schools, currently in Zimbabwe and indeed globally, ODL is seen as the future mode of learning. People are now more and more interested in flexible ways of learning such as online learning, through learning platforms that allow them time to do other things such as going to work etc and at the same time get an education. For example, some institutions globally are now using webinars to teach a wide audience of learners or MOOCS (Multiple Open Online Courses) among others. This is the thrust of this model that I am advocating. The model enables the production of many teachers at the same time in situations where teachers are in short supply.

Currently in Zimbabwe, the Ministry of Primary and Secondary Education has changed legislation by coming up with The Curriculum Framework for Primary and Secondary Education 2015 - 2022 [20], which is set to be rolled out starting 2016 with Phase 1, the development and printing of syllabuses for all levels of learning. The implementation, Phase 2, is set to start in 2017 and it is hoped that by 2022, there will be full implementation of the new curriculum. The new curriculum introduces new subjects at both Primary and Secondary School. For example, new subjects introduced by the new curriculum framework at the infant school are indigenous languages as a medium of instruction, visual and performing arts, mass displays, mathematics and science, family and heritage studies and Information and communication studies (ICT). The new subjects are to be introduced right across the curriculum and at all levels of Primary and Secondary Education.

Such reform in Zimbabwean Education is indeed good for the students and innovation in Zimbabwe. There has never been a curriculum reform of this magnitude done before and after independence. Like all British former colonies, we tended to follow the British style of learning up until now (see Ashby) [21]. Hence, the introduction of Heritage Studies, indigenous languages as a medium of instruction, expressive arts among others heralds in a new era in Zimbabwean education and will be good for the students and teachers. With regard to the ODL model for teacher development I am leading at ZOU, this means that there is need to staff develop all the teachers in Zimbabwe so that they are able to teach and handle the new curriculum. In that regard, this model of teacher development I am spearheading will become very useful for the training of many teachers through ODL while they remain working within the schools.

In the views of respondents, the following are some of the advantages offered by the model:

1. Large student numbers: The ODL model of teacher development has advantages and one such advantage is that it can accommodate many students for training at the same time as there are no space limitations among other advantages. As such many students can graduate at the same time. Hence alleviating the problem of teacher shortages quickly.

2. Flexibility: Moreover, the model offers flexibility in terms of study time as students study at their own pace.

3. Affordability: Where student numbers are large, the fees charged for the courses can be made affordable to the students through economies of scale. Hence it can be cheaper than conventional institutions.

4. Learn while you earn: Additionally students can learn while working and earning a living. This makes their lives easier as they can continue with their normal lives and at the same time acquire their qualifications.

5. Students are always stationed and working within a school hence they have more time to practice their teaching skills unlike at conventional colleges.

6. ICT can be used to advantage for the development of teachers through ICT based methods of instruction to go with this ICT age.

Scholars have surfaced similar advantages of Open and Distance Learning. For example, Brown and Brown, [1], mention a number of advantages for student empowerment through ODL as follows: flexibility of time, ability to empower large numbers of students at the same time, no space limitations, distance between the tutor and tutee is zero due to ICT; reading material has become abundant among others. 


\section{Conclusions}

In conclusion, the above ODL model of teacher development is still a work in progress and the author is open to ideas that enhance the model from colleagues locally, regionally and globally. Briefly, the model can be used as a guide to develop teachers in large numbers over a period of 3 years to solve the problem of teacher shortages in developing countries. The economic significance of this model is that a country can develop a large number of teachers at the same time. More importantly is the fact that the teachers can do their training while at work, teaching and earning a living for their families. There are no replacement teachers required as the teachers do not need to go on study leave to develop themselves. For this model, the quality assurance framework requires prospective candidates to have a minimum entry qualification of five (5) 'O' Level subjects including English Language, Mathematics, and Science with a $\mathrm{C}$ or better grade. 'A' Level, diplomas and certificates give applicants an added advantage. Furthermore, production of modules is also quality assured at various levels, at writing, content review and editing and proof reading is done at every stage, and finally, the Quality Assurance Unit goes over the completed module before it is published. Moreover, training workshops for module writers should be conducted. Additionally, Teaching Practice should be carried out by school based personnel and university lectures complemented by external assessors and examiners from other universities and colleges.

\section{Acknowledgements}

I would like to acknowledge and appreciate the work done by colleagues in the Zimbabwe Open University Department of Teacher Development for their inputs and suggestions during the development of this model. Further acknowledgements go to colleagues in the Regional Campuses of the University for their Contributions during the survey.

\section{REFERENCES}

[1] B. F. Brown, and Y. Brown. Distance Education around the World. In B. Willis (Ed.). Educational Technology. Englewood Cliffs, New Jersey, 1994.

[2] UNESCO. Teacher Education Through Distance Learning:
Technology - Curriculum - Cost - Evaluation. UNESCO, Paris, 2001.

[3] UNESCO. The Dakar Framework for Action. Education for All: Meeting our Collective Commitments. UNESCO, Paris, 2000.

[4] UNESCO. World Education Report: Teachers and Teaching in a Changing World. UNESCO, Paris, 1998.

[5] Organisation for Economic Cooperation and Development (OECD). Education Policy Analysis. 2001.

[6] B. Robinson. 'Distance education for primary teacher training in developing countries' in J. Lynch (1997)

[7] B. J. Siyakwazi. A history of Teacher Education in Colonial Zimbabwe 1928 to 1980. Booklove Publishers, Gweru. 2014.

[8] Rhodesia Director of African Education Report, pp. 21. 1920.

[9] Hadfield Commission Report, pp 10 - 15. 1925.

[10] Bone. R. C. African Education in Rhodesia: The Period to 1927 in "The Occasional Paper, No. 9. University of Rhodesia”. Salisbury. 1970.

[11] Kerr Commission Report, pp. 9 - 12. 1951.

[12] Rhodesia Government notice no. 676, November. Government Printers. Salisbury. Pp.2. 1929.

[13] F. B. Rea. The Future of Mission Education in Southern Rhodesia. The International Review of Missions, Vol. No. 49. Pp. $195-200.1960$.

[14] Rhodesia A/Director of Native Development Report, pp. 5. 1934.

[15] Rhodesia Director of Native Development Report, pp. 32. 1953.

[16] B. Siyakwazi and P. Siyakwazi. A history of the new approach to infant education of the 1960's to 1990s in Zimbabwe. Booklove Publishers, Gweru. 2012.

[17] Rhodesia Annual Report of the Secretary for African Education pp. 8. 1968 .

[18] Rhodesia Government. Education Policy. Government Printers. Salisbury. 1966

[19] M. Burns. Distance Education for Teacher Training: Modes, Models and Methods. Education Development Centre Inc. Washington DC. 2011.

[20] Zimbabwe Government. The Curriculum Framework for Primary and Secondary Education 2015 - 2022. 2015.

[21] Ashby, E. African Universities and Western Tradition. London. Oxford University Press. 1964. 